EESTI NSV TEADUSTE AKADEEMIA TOIMETISED. XV KÖIDE

FOUSIKA-MATEMAATIKA- JA TEHNIKATEADUSTE SEERIA. 1966. NR. 2

ИЗВЕСТИЯ АҚАДЕМИИ НАУК ЭСТОНСКОИ ССР. ТОМ ХV

СЕРИЯ ФИЗИКО-МАТЕМАТИЧЕСКИХ И ТЕХНИЧЕСКИХ НАУК. 1966, № 2

\title{
ОТЛОЖЕНИЯ ШЯШУВСКОЙ И ВИЕСИТСКОЙ СВИТ НА ТЕРРИТОРИИ ЭСТОНИИ
}

До последнего времени было принято считать, что разрез девонских терригенных пород, отлагающихся после длительного перерыва на размытой поверхности карбонатных пород ордовика и силура, начинается на территории Эстонии и прилегающей к ней северной части Латвии отложениями пярнуского горизонта живетского яруса среднего девона. Увеличение мощности этого горизонта в Южной Әстонии и Северной Латвин объясняли тектоническими причинами. Северная граница распространения нижнего девона проходила через Южную Латвию, поворачивая на север только в районе Курземского полуострова (см. рисунок). В Средней Латвии под пярнуским горизонтом выделялась мощная толща алевритисто-песчанистых пород, называемая кемерской свитой (средний девон, эйфельский ярус). Мощность этой свиты достигала в Средней Латвии местами $110-130$ м.

Весной 1965 года в Северной Латвии в окрестностях Буртниекского озера в нижней части предполагаемого пярнуского горизонта были обнаружены остатки раннедевонской рыбы Pteraspis. Эта находка потребовала пересмотра стратиграфии терригенных отложений низов девона Эстонии. Ревизия материала привела к положительным результатам. Но так как находки фауны в нижней части песчано-алевритистого разреза девона практически отсутствуют и нет явньіх макролитологических границ, то было трудно отделить отложения нижнего девона от эйфельского яруса. Для установления границ между названными стратиграфическими единицами и между эйфельским и живетским ярусами были использованы два математических метода - метод тренда А. Вистелиуса [1] и метод статистической теории однородных геологических совокупностей Д. Родионова $\left.{ }^{2}\right]$. При этом наши разрезы сопоставлены с разрезами Курземского полуострова, где уже раньше под пярнуским горизонтом были выделены отложения стонишкяйской свиты нижнего и кемерской свиты среднего девона. Используя литологические, минералогические и геохимические данные, с помощью названных математических методов были установлены достоверные границы между нижним и средним девоном и между ярусами среднего девона. Оказалось, что верхняя граница нижнего девона по этим данным находится примерно на 15 выше границы, проведенной латвийскими геологами в буровых скважинах Курземского полуострова. В 1964 году литовские геологи В. Талимаа, В. Нарбутас и В. Василяускас $\left[{ }^{3-5}\right]$, основываясь на фаунистических данных, разделили кемерскую свиту на шяшувскую и виеситскую свиты, первая из которых принадлежит к нижнему, вторая - к среднему девону. На территории Эстонии, по-видимому, встречаются обе эти свиты. 
Стонишкяйская свита, подстилающая шяшувские отложения, в наших разрезах, по всей вероятности, отсутствует. Во всяком случае, нет никаких данных для выделения еще одного стратиграфического подразделения. Кроме того, следует подчеркнуть, что по материалам литовских геологов стонишкяйские и шяшувские свиты трудно отделить друг от друга.

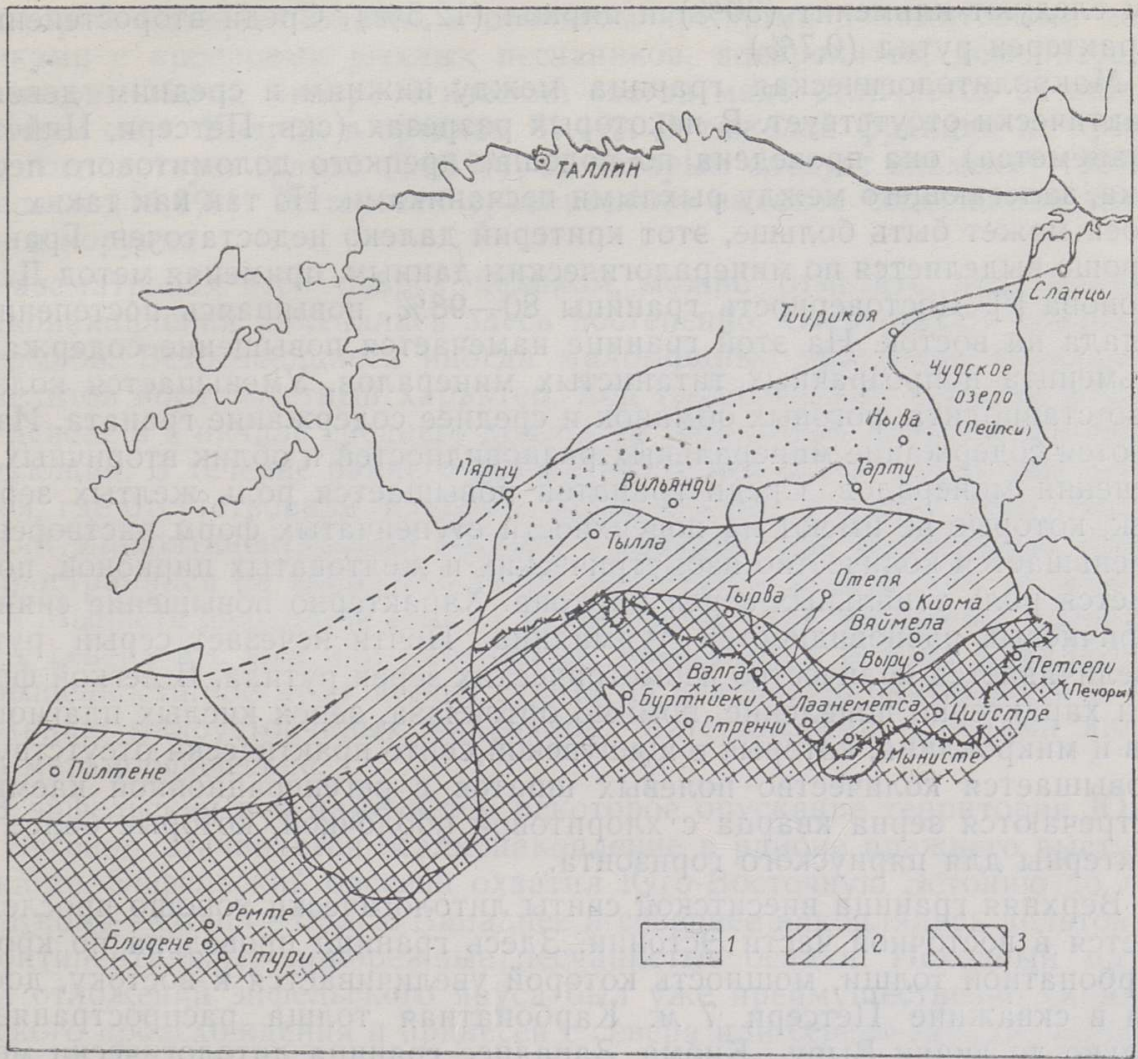

Карта распространения нижней песчанистой толщи девона. Зоны распространения: 1 - пярнуский горизонт; 2 - виеситская свита; 3 - шяшувская свита.

Отложения нижнего девона обнаружены в Эстонии в пяти буровых скважинах (Петсери, Цийстре, Лаанеметса, Валга и Тырва). Они распространяются узкой полосой в Южной Эстонии от Петсери (Печоры) до Мыйзакюла, отсутствуя в районе поднятия Мынисте (см. рисунок), и г!редставлены хорошо отсортированными рыхлыми мелкозернистыми пес-чаниками и алевролитами. Максимальная мощность достигает 26,8 м (скв. Лаанеметса). По минералогическому составу песчаники олигомиктовые (кварца 84\%), в тяжелой фракции господствуют гранат $(46 \%)$, ильменит $(20 \%)$ и циркон $(12,5 \%)$. Из второстепенных минералов характерно присутствие ставролита, роговых обманок, иногда и клиноцойзита и эпидота.

Среднедевонский разрез начинается с виеситской свиты эйфельского яруса. В Восточной Әстонии эти отложения распространяются почти до p. Эмайыги, но начиная от г. Тарту к западу зона распространения постепенно становится все у́же (см. рисунок). Мощность виеситской свиты 20-30 м с увеличением с севера на юг. Аномальной является мощность

7 ENSV TA Toimetised F-2 66 
свиты в скважине Киома - 38 м. Отложения представлены мелкозернистыми рыхлыми песчаниками с алевритистыми прослойками. Встречаются маломощные комплексы с карбонатным цементом, особенно в кровле свиты, но иногда и в ее подошве. Как правило, верхняя половина разреза более или менее карбонатная. Минералогический состав олигомиктовый (кварца $82,5 \%$ ). Из тяжелых минералов преобладает гранат $(35 \%)$, затем следуют ильменит $(30 \%)$ и циркон $(12,5 \%)$. Среди второстепенных характерен рутил $(0,7 \%)$.

Макролитологическая граница между нижним и средним девоном практически отсутствует. В некоторых разрезах (скв. Петсери, Цийстре, Лаанеметса) она проведена по подошве крепкого доломитового песчаника, залегающего между рыхлыми песчаниками. Но так как таких прослоек может быть больше, этот критерий далеко недостаточен. Граница хорошо выделяется по минералогическим данным, применяя метод Д. Родионова [2]. Достоверность границы $80-98 \%$, повышаясь постепенно с запада на восток. На этой границе намечается повышение содержания иліменита и прозрачных титанистых минералов. Уменьшается количество ставролита, роговых обманок и среднее содержание граната. Изменяются содержание минеральных разновидностей и облик втсричных изменений минералов. Среди гранатов повышается роль желтых зернышек, которые не имеют на поверхности ступенчатых форм растворения. Уменьшается количество изометрических и желтоватых цирконов, повышается роль зональных зерен циркона. Характерно повышение синих и коричневых разновидностей турмалина. Почти исчезает серый рутил. Увеличивается количество изометрических зерен рутила. В легкой фракции характерно появление, помимо ортоклаза, зерен кислых плагиоглазов и микроклина, которые в шяшувской свите практически отсутствуют. Повышается количество полевых шпатов с регенерационной каемкой. Встречаются зерна кварца с хлоритовой оболочкой, которые более характерны для пярнуского горизонта.

Верхняя граница виеситской свиты литологически хорошо прослеживается в восточной части Әстонии. Здесь граница проведена по кровле карбонатной толщи, мощность которой увеличивается к востоку, достигая в скважине Петсери 7 м. Карбонатная толща распространяется голько до линии Выру-Қиома. Западнее граница литологически менее ясна. Обычно она проводится по кровле алевролитов, песчаников или глин с карбонатным цементом, над которыми залегает толща рыхлых песчаников пярнуского горизонта. Но в некоторых случаях пярнуский горизонт начинается крепкими песчаниками (скв. Тылла), алевролитами (скв. Лаанеметса) или глинами (скважины Мынисте и Выру). Минералогически граница достоверная, хотя достоверность ее ниже, чем у нижней границы (в среднем 85\%). Для пярнуского горизонта характерно повышение содержания циркона, корунда и титанистых минералов, особенно титанита. Уменьшается количество апатита, ильменита и ставролита. Из минеральных разновидностей увеличивается еще количество желтых гранатов, синих и коричневых турмалинов, зональных зерен циркона. Появляются красновато-коричневые и янтарно-желтые рутилы. Чаще попадаются коленчатые двойники рутила. Сильно увеличивается количество зерен кварца с мозаичным или волнистым погасанием. Характерна сильная хлоритизация кварцевых зерен. Интересной чертой являются сагенитовые включения на листах хлорита и мусковита, которые особенно характерны для наровского горизонта. Достоверную границу между виеситской свитой и пярнуским горизонтом, наверно, можно установить при помощи геохимических данных, но, к сожалению, последних в распоряжении автора было очень мало. В двух случаях, когда они 
применялись (скважины Стури и Лаанеметса), были получены отличные результаты.

Пярнуский горизонт в Эстонии представлен песчанистыми и алевритистыми породами мощностью до 41,5 . Относительное количество песчаников здесь несколько выше, чем в нижележащих подразделениях. Песчаники залегают в нижней части разреза, тогда как верхняя половина горизонта представлена в основном крепкими доломитовыми песчаниками с прослоями рыхлых песчаников, алевролитов, домеритов и доломитов. Общий минералогический состав мало отличается от нижележащих свит. Кварца в среднем $81,4 \%$. В тяжелой фракции по-прежнему господствует гранат $(34,5 \%)$, за которым следует ильменит $(30 \%)$ и циркон $(14,6 \%)$. Интересно сравнительно высокое содержание тита-ніиа и корунда.

Рассматривая весь разрез целиком, можно отметить, что условия осадконакопления изменялись здесь постепенно. Отсутствуют признаки перерывов. Встречающиеся иногда маломощные прослойки брекчии и гравелитов носят местный характер. Ход геологических событий в раннем девоне и в начале среднего девона на территории Эстонии мог быть следующий. В течение раннего девона почти вся наша территория была сушей, где отсутствовали процессы седиментации. Только к концу эпохи мелкий эпиконтинентальный бассейн с пресной или полупресной водой распјјостранился на южную окраину территории республики. В окрестности Мынисте находился выступ фундамента. Сток материала происходил с севера и с юга или юго-запада, возможно, с района Сувальской визвышенности. Об этом можно судить по изменению окатанности и со- держанию малоустойчивых минералов. Материнскими породами являлись метаморфические.

В эйфельский век намечается некоторое опускание территории Южной Әстонии. Начинается осадконакопление в районе прежнего выступа Мынисте. Эйфельский бассейн охватил Юго-Восточную Эстонию до линии Кноа-Отепя-Валга. Западнее и севернее накоплялись дельтовые и континентальные прибрежные песчанистые осадки. Исходный материал отложений эйфельского яруса был уже преимущественно скандинавского происхождения и принесен с севера или северо-запада, частью, может быть, даже с северо-востока. Материнскими породами явились метаморфические породы.

В пярнуское время территория распространения осадков увеличилась еще больше, особенно к северу. В начале этого времени намечается некоторое поднятие. Накопляются преимущественно континентальные прибрежные и речные пески. Существуют два отдельных бассейна: один с џентром в северной части нынешнего Чудского озера, другой - в районе Мынисте-Цийстре-Лаанеметса. Во второй половине описываемого времени отмечается повсеместное опускание территории. К пярнускому времени южный источник сноса потерял свое значение. Основными источниками сноса остались Скандинавские горы.

Материал, приведенный в настоящей статье, требует еще дальнейшей разработки. При помощи спектрального анализа следует выяснить ход геохимических изменений. Границы распространения описываемых стратиграфических единиц надо установить более точно. 


\section{ЛИТЕРА Т У РА}

1. Vistelius A. B., Sedimentation time trend functions and their application for correlation of sedimentary deposits, J. Geol., 69, No. 6, Nov. 1961.

2. Р оди инов Д. А., К вопросу о статистической теории однородности геологических совокупностей, Геохимия, № 4 (1965).

3. К а р а т а ют.е-Т алима а В. И. и Н а р 6 у т а с В. В., О выделении шяшувской свиты в разрезе девона польско-литовской синеклизы, Сб. Вопросы стратиграфии и палеогеографии девона Прибалтики, Вильнюс, 1964.

4. Н а рбутас В. В., Некоторые черты геологического развития Южной Прибалтики в ранне- и среднедевонское время, Сб. Вопросы геологии Литвы, Вильнюс, 1963.

5. Нарбутас В. В., В асильяускас В. М., Коркути с В. А., Новые данные к познанию палеогеографии и тектоники Южной Прибалтики в ранне- и среднедевонское время, Сб. Вопросы стратиграфии и палеогеографии девона Прибалтики, Вильнюс, 1964.

\section{A. KLEESMENT}

\section{ŠJAŠUVI JA VIESITE KIHISTU SETTED EESTI TERRITOORIUMIL}

Kuni käesoleva ajani arvati kogu devoni alumine terrigeenne kompleks keskdevoni pärnu lademesse. 1965. aastast nende kihtide alumisest osast Põhja-Lätist pärinev alamdevoni faunaleid sundis seniseid seisukohti ümber hindama. Selgus, et Eesti territooriumi Iounaosas esinevad pärnu lademe all alamdevoni šjašuvi ja keskdevoni viesite kihistu setted. Oma litoloogiliselt iseloomult erinevad viimased pärnu lademest vähe. Eraldamise aluseks olid põhiliselt muutused setete mineraloogilises koosseisus.

\section{A. KLEESMENT}

\section{THE DEPOSITS OF THE SHYASHUV AND VIESITE FORMATIONS ON THE TERRITORY OF ESTONIA}

Up to the present time, the entire lower terrigenous sequence of the Devonian of Estonia was attributed to the Middle Devonian Pärnu stage. In 1965, however, recovery of the Lower Devonian fauna in the lower parts of these beds in northern Latvia brought about a revision of this standpoint. It appears that, in the southern part of Estonia under the Pärnu stage there occur deposits of the Lower Devonian Shyashuv and Middle Devonian Viesite formations. Lithologically they differ but inconsiderably from the Pärnu stage. The basis of the new correlation lies mainly in the differences in the mineralogical character of these deposits. 